\title{
Prognostic Impact of 25-Hydroxyvitamin D Levels in Egyptian Patients with Breast Cancer
}

\author{
Shereen El-Shorbagy ${ }^{1 *}$, Rasha Haggag ${ }^{1}$, Huda F Ebian², Hany A Labib ${ }^{2}$ and Ola A Harb ${ }^{3}$ \\ ${ }^{1}$ Department of Medical Oncology, Faculty of Medicine, Zagazig University, Zagazig, Egypt \\ ${ }^{2}$ Department of Clinical Pathology, Faculty of Medicine, Zagazig University, Zagazig, Egypt \\ ${ }^{3}$ Department of Pathology, Faculty of Medicine, Zagazig University, Zagazig, Egypt
}

\begin{abstract}
Background: According to the literature, vitamin $\mathrm{D}(\mathrm{Vit} \mathrm{D})$ deficiency is a risk factor for breast cancer developing with lack of information on its direct prognostic effects in breast cancer.

Patients and methods: A total of 168 women with proven breast cancer diagnosed in Zagazig university hospitals- Egypt were enrolled in this study. Serum level of $25(\mathrm{OH})$ Vit $D$ was measured in stored blood just after diagnosis. Vit D levels were classified into three groups: deficient: $<10 \mathrm{ng} / \mathrm{ml}$; insufficient: $10 \mathrm{ng} / \mathrm{ml}$ to $30 \mathrm{ng} / \mathrm{ml}$; and sufficient: $>30 \mathrm{ng} / \mathrm{ml}$. Clinical-pathological data and disease outcome were accessed to examine prognostic effect of vitamin $D$ in breast cancer.

Results: Median age was 51.5 (26-77) years, Metastasis was present in $13.1 \%$ of the cases. The median serum level of $25(\mathrm{OH})$ Vit D was $20(5-98) \mathrm{ng} / \mathrm{ml}$; it was deficient in $36.9 \%$ of patients, insufficient in $32.1 \%$ of patients, and sufficient in $31 \%$ of patients. Serum level of $25(\mathrm{OH})$ VitD levels decreased significantly with increasing body mass index $(\mathrm{BMI})(\mathrm{P}=0.00)$, also the relations of $25(\mathrm{OH})$ Vit $\mathrm{D}$ level with the number of positive lymph nodes, tumor size, tumor stage and KI 67 level were statistically significant $(p=0.01, p=0.011, p=0.002, p=0.001$ respectively). The level of $25(\mathrm{OH})$ vitamin $D$ was significantly low in metastatic patients $(p=0.01)$. For those non -metastatic $B C$ patients; there was no statistically significant difference in mean Disease-Free Survival (DFS) times across the 3 categories of serum Vitamin $D(p=0.13)$, also for metastatic patients, serum vit $D$ level didn't affect the median PFS $(p=0.98)$. The mean OS of the 3 different categories of serum vit $D$ (sufficient, insufficient and deficient) were 45.8 months, 39.7 months and 39 months respectively $(p=0.047)$. Univariate analysis, showed that OS was significantly affected by age, BMI, grade, stage, molecular type and vit $D$ levels $(p=0.014, p=0.002, p=0.002, p<0.0001$, and $p=0.047$ respectively), but in Multivariate analysis: age, BMI, stage, and vit $D$ levels were the only independent factors significantly affect the OS $(p=0.01,0.001, p<0.0001$ and $p=0.022$, respectively).
\end{abstract}

Conclusion: There may be an association between serum $25(\mathrm{OH})$ Vit D level and breast cancer prognosis.

Keywords: Breast cancer; Vitamin D; Prognosis

\section{Introduction}

Breast cancer is the most common malignancy in women in the world [1]. In Egypt, the most common cancer among females is breast cancer, estimating $32.04 \%$ according to the results of the National Population-Based Registry Program of Egypt 2008-2011 [2]. Because of the extent of such type of cancer; extensive studies have been done to recognize risk factors seeking to decrease the incidence. The life style and environmental factors which could be changeable variables have been linked with reduced breast cancer risk [3]. Vitamin D (vit D) is a fat-soluble vitamin which controls level of calcium and homeostasis of bone, but also has adverse property linked to cancer development. Vit D is gained from dietetic resources like prepared dairy food, cereals, and supplements. Though, up to ninety percent of this vitamin is created in nature in our bodies after UVB light strikes the originator particle in skin. After vit D go through many processes in liver to structure 25-hydroxyvitamin D (25-OHD), which is most important circulating metabolite, then to kidneys to form 1,25-dihydroxyvitamin $\mathrm{D}$, which is the major biologically active form [4]. The antitumor effects of activated vit $\mathrm{D}$ occurred through vit $\mathrm{D}$ receptor which forms a nuclear receptorbond complex that controls target genes expression like p27, p21, c-myc, and c-fos [5]. According to previous literatures, vit D deficiency is considered as a risk factor for breast cancer development [6-10]. The cells as well as normal and malignant breast cells. Many studies revealed that vit D can hinder the cell growth of other malignant cells other than breast cancer like prostate, colon, ovary and myeloid leukemia [11]. Laboratory studies and epidemiology researches incriminate vitamin $\mathrm{D}$ insufficiency in breast cancer development. In vitro, researches clarify that 1,25 dihydroxyvitamin $\mathrm{D}$ hinders the increase of breast cancer cell, enhances differentiation and apoptosis [12]. Vitamin D adequacy and exposure to sunlight have been shown to decrease the risk of breast cancer development [6]. There have been merely a small number of studies that investigate the effect of vit $\mathrm{D}$ level at diagnosis on breast cancer survival [13-16], from the 5 studies examined the relation between serum vit D and BC mortality, 3 reported a significant decrease in death rates in patients with high vit D levels [14-16]. One study detected a valuable outcome but that was not statistically significant [11], whereas the $5^{\text {th }}$ trial found a positive effect in the age-adjusted but not in multivariate analysis [13].

In view of high prevalence as well as magnitude of breast cancer and its link to Vit D serum level, we conducted this study to evaluate vitamin $\mathrm{D}$ level in breast cancer patient in our community at diagnosis, and find out the correlation between its level and breast cancer prognosis.

*Corresponding author: Shereen EL Shorbagy, Department of Medical Oncology, Faculty of Medicine, Zagazig University, Zagazig, Egypt, Tel: 2010927 2819; E-mail: elshorbagy@hotmail.com

Received May 03, 2017; Accepted June 26, 2017; Published June 27, 2017

Citation: El-Shorbagy S, Haggag R, Ebian HF, Labib HA, Harb OA (2017) Prognostic Impact of 25-Hydroxyvitamin D Levels in Egyptian Patients with Breast Cancer. J Cancer Sci Ther 9: 496-502. doi: 10.4172/1948-5956.1000466

Copyright: ( 2017 El-Shorbagy S, et al. This is an open-access article distributed under the terms of the Creative Commons Attribution License, which permits unrestricted use, distribution, and reproduction in any medium, provided the original author and source are credited. 


\section{Materials and Methods}

\section{Subjects}

In this patient-cohort study, 168 breast cancer females, diagnosed at Zagazig university hospitals-Egypt were enrolled during the period between 2013 and 2015. Inclusion criteria were: women with histologically confirmed breast cancer at first presentation. Exclusion criteria were: concurrent or prior other type of malignancy, history of calcium or vitamin D supplements, chronic renal disease, liver disease, hyperthyroidism, malabsorption syndrome, or patients taking drugs as anticonvulsants, glucocorticoids, immunosuppressant. (Informed consent was obtained from each patient; this study was approved by Zagazig university Institutional review board (IRB)). Blood sample was obtained to measure $25(\mathrm{OH})$ Vit $\mathrm{D}$ levels following diagnosis before any treatment (either chemo, radiotherapy or hormonal). Vit D level classified into three groups: deficient: $<10 \mathrm{ng} / \mathrm{ml}$; insufficient: $10 \mathrm{ng} /$ $\mathrm{ml}$ to $30 \mathrm{ng} / \mathrm{ml}$; and sufficient: $>30 \mathrm{ng} / \mathrm{ml}$ [17]. Clinical stage of cancer, body mass index (BMI) which was calculated as a person's weight in kilograms divided by her height in meters squared. (Normal weight is considered at a BMI of $18.5-24.9$, underweight is $<18.5$, overweight is 25-29.9 and obese at BMI of >30) [18]. And performance status (PS) according to ECOG scale [19] were evaluated by physician. Histological type, grade and status of ER, PR, HER2 and Ki-67 were determined through IHC staining by our pathologist. All patients were followed up for a median follow up of 46 months by regular visit every 3 months, in which; clinical examination, chest X-ray, pelvi-abdominal U/S, and any other investigations which were needed according to patients' complaints were done.

\section{Measurement of plasma 25-OHD}

Principle by Hitachi. ROCHE. Cobas et al.

Competition principle: Total duration of the assay is 27 minutes.

$1^{\text {st }}$ incubation: The sample was $(15 \mathrm{ul})$. Vit $\mathrm{D}(25-\mathrm{OH})$ is released from vit $\mathrm{D}$ binding protein was pretreated and incubated with reagent (1) and (2). $2^{\text {nd }}$ incubation: Incubate vit D $(25-\mathrm{OH})$ with sample, labeled with ruthenlum binding protein as a complex that formed between both. $3^{\text {rd }}$ incubation: added microparticles coated with streptaviridin and vit D (25-OH) labeled with protein, unbound ruthenlum labeled vit D binding protein become occupied. Vit D (25-OH) labeled with biotin formed complex with Vit D ruthenglated binding protein and the compound bounded to solid phase via interaction of biotin and streptavidin. The reaction mix was aspirated into measuring cell, where the micro particles were magnetically captured on to the surface of the electrode, unbound substance first removed from procell then measured by photomultiplier through chemi-luminescent emission. Results were determined via calibration curve which was specific for instrument.

We used American Joint Committee on Cancer staging system classification (AJCC $7^{\text {th }}$ edition) for cancer staging [20] and the Nottingham (Elston-Ellis) modification of the Scarff Bloom Richardson grading system for grading [21]. We identified patient age, cancer size, grade, stage and histopathological subtype by examination of the patient's and the slide files of the pathology department. ER, PR hormonal receptors and Her2 neu expressions and Ki67 labeling index were evaluated for all cases.

\section{Immunohistochemical staining}

Streptavidine-biotin technique was used for immunohistochemical staining with primary monoclonal mouse anti- HER-2/neu Ab-20 (L87
$+2 \mathrm{ERB} 19$ ) diluted $1 / 200$ at $4^{\circ} \mathrm{C}$ overnight (Thermo Fisher Scientific, Lab Vision Corporation, Fremont, USA) and estrogen receptor (ER, Clone 6F11, Ventana 760-2596, prediluted), progesterone receptor (PR, Clone 1A6, Ventana 760-2547, prediluted) and Ki67 (clone MIB-1, DAKO M7240, dilution 1:70) [22].

Evaluation of immunohistochemical expression of ER and PR receptors: We scored nuclear staining in cancer cells semi-quantitatively by combining both intensity and extent of stain. The intensity was graded from 0 (negative) to 3 (strong). The extent was graded as 0 (negative expression), 1 (positive expression in less than $10 \%$ of cancer cells), 2 (positive expression in 10\% to $50 \%$ of the tumor cells) and three (positive expression in greater than $50 \%$ of the tumor cells).

The final score $(0-10)$ was reached by multiplying both the staining intensity and extent scores. A final cut off staining score of less than 4 was interpreted as low expression and a score equal to or more than 4 was interpreted as high expression [23].

Evaluation of immunohistochemical expression of Her2 neu: We scored membranous staining and the degree of immunostaining was scored as followed: $0=$ no-reactivity or only membranous reactivity in less than $10 \%$ of cancer cells, $1=$ faint membranous stain in more than $10 \%$ of cancer cells; $2=$ weak to moderate membranous stain in more than or equal $10 \%$ of cancer cells and $3=$ strong complete membranous stain in more than $10 \%$ of cancer cells [24].

Evaluation of immunohistochemical expression of Ki 67: Only distinct nuclear staining of invasive carcinoma cells was used for scoring which was determined semi quantitatively as negative (no stain), low ( $10 \%$ or less immunoreactive cells) or high ( $>10 \%$ immunoreactivity) respectively [25].

\section{Statistical Analysis}

Continuous variables were expressed as the mean \pm SD and median (range), and the categorical variables were expressed as a number (percentage). Continuous variables were checked for normality by using Shapiro-Wilk test. Percent of categorical variables were compared using the Pearson's Chi-square test or Fisher's exact test when was appropriate. Trend of change in distribution of relative frequencies between ordinal data were compared using Chi-square test for trend. All tests were two sided. A p-value $<0.05$ was considered significant. All statistics were performed using SPSS 22.0 for windows (SPSS Inc., Chicago, IL, USA) and MedCalc windows (MedCalc Software bvba 13, Ostend, Belgium). The Kaplan-Meier technique was used to analyze the OS, PFS and DFS.

\section{Results}

\section{Patient's characteristics}

We enrolled 168 breast cancer cases, mean age was 51.6 year and with median age was 51.5 (26-77) years, metastasis was present in $13.1 \%$ of the cases. Stage of tumor was I, II, III and IV in $15.5 \%, 34.5 \%$, $36.9 \%$ and $13.1 \%$ of patients, respectively. The Tumor grade was low in $11.9 \%$ of cases, intermediate in $63.3 \%$ of cases, and high in $26.8 \%$ of cases. The Ki-67, HER 2-neu, ER and PR were positive in 35.7\%, 32.7\%, $69 \%$ and $64.3 \%$ of the cases, respectively.

Mean vitamin D level was $28.7 \mathrm{ng} / \mathrm{ml}$, and median was $20 \mathrm{ng} / \mathrm{ml}$ (range, $5 \mathrm{ng} / \mathrm{ml}$ to $98 \mathrm{ng} / \mathrm{ml}$ ). Vitamin D levels were deficient in 62 patients (36.9\%), insufficient in 54 patients (32.1\%), and sufficient in 52 patients (31\%). Vitamin D levels decreased significantly with increasing BMI $(\mathrm{P}=0.00$; Table 1). The relation of $25(\mathrm{OH})$ Vit $\mathrm{D}$ level with age, 
Citation: El-Shorbagy S, Haggag R, Ebian HF, Labib HA, Harb OA (2017) Prognostic Impact of 25-Hydroxyvitamin D Levels in Egyptian Patients with Breast Cancer. J Cancer Sci Ther 9: 496-502. doi: 10.4172/1948-5956.1000466

and patient performance status was not statistically significant $(\mathrm{p}=0.91$, $\mathrm{p}=0.74$ respectively). No statistically significance difference was found in Vitamin D levels according to menopausal status ( $\mathrm{p}=0.69$ ).

Vitamin D level and tumor characteristics: The relation of 25 $(\mathrm{OH})$ Vit $\mathrm{D}$ level with the number of +ve lymph nodes, size of tumor, tumor stage and KI 67 level was statistically significant $(p=0.001$, $\mathrm{p}=0.011, \mathrm{p}=0.002, \mathrm{p}=0.001$ respectively). $25(\mathrm{OH})$ vitamin D level was significantly low in metastatic cases $(\mathrm{p}=0.01)$. Regarding molecular subtypes, luminal B had significant deficient vit d level while luminal A had significant sufficient levels ( $\mathrm{p}=0.03$ ).

Also, the BMI was statistically significant high in metastatic patients in comparison to non-metastatic patients $(p=0.01)$. BMI was significantly higher in Her2 Rich cases in comparison to Her2 negative cases ( $\mathrm{p}=0.01$ ), but no significant relation to ER or PR status ( $\mathrm{p}=0.22$, $\mathrm{p}=0.25$ respectively).

Vitamin D level and breast cancer survival: After median follow up of 46 (45.4-46.5) months; the study containing 144 of non-metastatic breast cancer and 24 metastatic breast cancers, the mean DFS for all non-metastatic patients was $38.617+1.08$ months and median DFS not reached.

For those non-metastatic BC patients; there was no statistically significant difference in mean disease-free survival (DFS) times across the 3 categories of serum Vitamin D ( $\mathrm{p}=0.13)$ (Figure 1).

The median PFS for all metastatic patients was 9 months (ranging from 4.2 months to 13.8 months), and for metastatic patients, serum vit $\mathrm{D}$ level didn't affect the median PFS ( $\mathrm{p}=0.98)$.

\begin{tabular}{|c|c|c|c|c|c|}
\hline Variables investigated & $\begin{array}{l}\text { Variables frequencies in all } \\
\text { patients }\end{array}$ & $\begin{array}{c}\text { Vit D deficient level (<10 } \\
\mathrm{ng} / \mathrm{dl})\end{array}$ & $\begin{array}{l}\text { Vit D Insufficient level } \\
\text { (10 ng/dl to } 30 \mathrm{ng} / \mathrm{dl})\end{array}$ & $\begin{array}{c}\text { Vit D Sufficient level } \\
(>30 \mathrm{ng} / \mathrm{dl})\end{array}$ & $p$ value \\
\hline \multicolumn{6}{|c|}{ Age } \\
\hline$<50$ years & $73(43.5 \%)$ & 19 & 29 & 25 & \multirow[b]{2}{*}{0.14} \\
\hline$>=50$ years & $95(56.5 \%)$ & 35 & 25 & 35 & \\
\hline Premenopausal & $74(44 \%)$ & 25 & 26 & 23 & \multirow{2}{*}{0.69} \\
\hline Postmenopausal & $94(56 \%)$ & 37 & 28 & 29 & \\
\hline \multicolumn{6}{|c|}{ Body mass index(BMI) } \\
\hline High & $65(38.7 \%)$ & 25 & 25 & 15 & \multirow{3}{*}{0.017} \\
\hline Intermediate & $69(41.1 \%)$ & 21 & 19 & 29 & \\
\hline Low & $34(20.2 \%)$ & 8 & 10 & 16 & \\
\hline \multicolumn{6}{|c|}{ Number of +ve L N } \\
\hline No & $62(36.9 \%)$ & 15 & 13 & 34 & \multirow{4}{*}{0} \\
\hline $\mathrm{N} 1$ & $31(18.5 \%)$ & 13 & 10 & 8 & \\
\hline N2 & $40(23.8 \%)$ & 18 & 15 & 7 & \\
\hline N3 & $35(20.8 \%)$ & 16 & 16 & 3 & \\
\hline \multicolumn{6}{|c|}{ Stage } \\
\hline 1 & $26(15.5 \%)$ & 7 & 7 & 12 & \multirow{4}{*}{0} \\
\hline II & $58(34.5 \%)$ & 16 & 12 & 30 & \\
\hline III & $62(36.9 \%)$ & 25 & 28 & 9 & \\
\hline $\mathrm{VI}$ & $22(13.1 \%)$ & 14 & 7 & 1 & \\
\hline \multicolumn{6}{|c|}{ Grade } \\
\hline Low & $20(11.9 \%)$ & 7 & 6 & 7 & \multirow{3}{*}{0.46} \\
\hline Intermediate & $103(61.3 \%)$ & 35 & 32 & 36 & \\
\hline High & $45(26.8 \%)$ & 20 & 16 & 9 & \\
\hline \multicolumn{6}{|c|}{ Ki-67 } \\
\hline High & $60(35.7 \%)$ & 31 & 20 & 9 & \multirow{2}{*}{0.001} \\
\hline Low & $108(64.3 \%)$ & 30 & 33 & 45 & \\
\hline \multicolumn{6}{|c|}{ Her2 } \\
\hline HER2+ve & $55(32.7 \%)$ & 21 & 20 & 14 & \multirow{2}{*}{0.27} \\
\hline HER2-ve & $113(67.3 \%)$ & 35 & 33 & 45 & \\
\hline \multicolumn{6}{|c|}{ ER } \\
\hline ER+ve & $116(69 \%)$ & 38 & 32 & 46 & \multirow{2}{*}{0.13} \\
\hline ER-ve & $52(31 \%)$ & 16 & 22 & 14 & \\
\hline & & & & & \multirow{3}{*}{0.43} \\
\hline PR+ve & $108(64.3 \%)$ & 36 & 31 & 41 & \\
\hline PR-ve & $60(35.7 \%)$ & 18 & 23 & 19 & \\
\hline \multicolumn{6}{|c|}{ Molecular subtype } \\
\hline 1-Her-2 rich & $21(12.5 \%)$ & 5 & 11 & 5 & \multirow{4}{*}{0.084} \\
\hline 2-luminal a & $77(45.8 \%)$ & 20 & 22 & 35 & \\
\hline 3-luminal b & $44(26.2 \%)$ & 20 & 12 & 12 & \\
\hline 4-triple -ve & $26(15.5 \%)$ & 9 & 9 & 8 & \\
\hline
\end{tabular}

Table 1: Frequencies and comparison of investigated variables based on Serum 25-Hydroxy Vitamin D Level. 


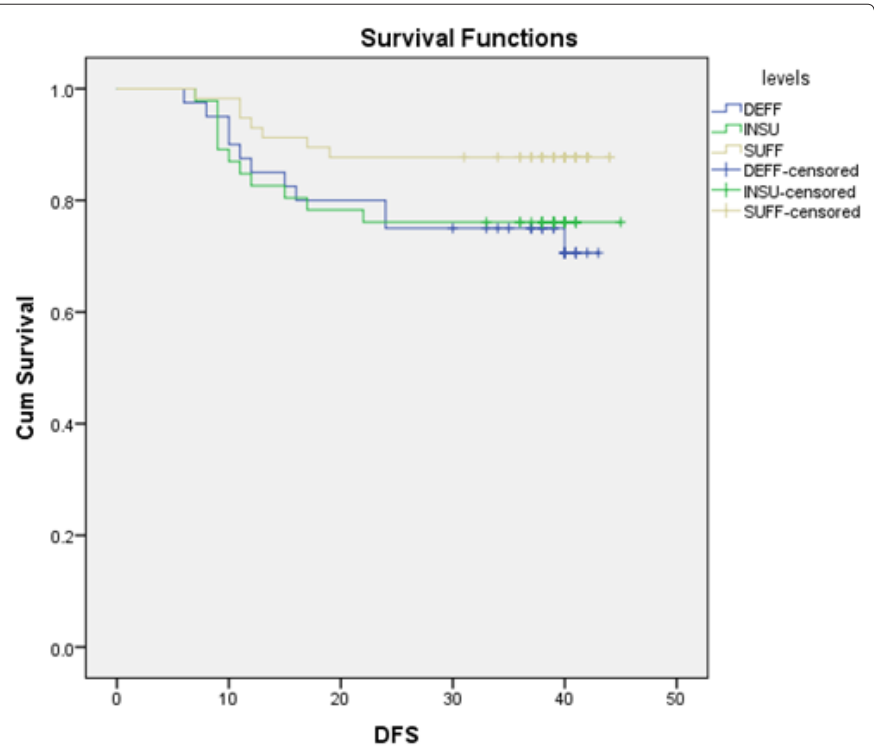

Figure 1: Disease Free Survival (DFS) of the 3 different category groups of serum vit $D$ in non-metastatic breast cancer patient.

The mean overall (OS) of all patients was $41.9+1.14$ months and median not reached.

The mean OS of the 3 different categories of serum vit $\mathrm{D}$ (sufficient level $>30 \mathrm{ng} / \mathrm{ml}$, insufficient level $10 \mathrm{ng} / \mathrm{ml}$ to $30 \mathrm{ng} / \mathrm{ml}$, and deficient level $<10 \mathrm{ng} / \mathrm{ml}$ ) were 45.8 months, 39.7 months and 39 months respectively ( $\mathrm{p}=0.047)$ (Figure 2).

Univariate analysis, showed that OS was significantly affected by age, BMI, tumor grade, tumor stage, molecular type and vit $\mathrm{D}$ levels ( $\mathrm{p}=0.014, \mathrm{p}=0.002, \mathrm{p}=0.002, \mathrm{p}<0.0001$, and $\mathrm{p}=0.047$ respectively), but in multivariate analysis, age, BMI, tumor stage, and vit D levels were the only independent factors significantly affect the OS ( $\mathrm{p}=0.01,0.001$, $\mathrm{p}<0.0001$ and $\mathrm{p}=0.022$, respectively) (Table 2 ).

\section{Discussion}

There is a rising concern to recognize the magnitude of environmental, way of life and nutritional factors, and how these may act together with genetic susceptibility to modify risk of cancer occurrence, and there is rising data for a bond between vitamin $\mathrm{D}$ and protection against breast cancer [26]. Because of the effect of vitamin $\mathrm{D}$ on different cell cycle pathways, its role in breast cancer (BC) development and progression has been meticulously examined. Though the literature is conflicting, many studies have revealed that sufficient vitamin $\mathrm{D}$ levels decrease the risk of $\mathrm{BC}$ and get better survival after diagnosis [27]. Patients with elevated plasma levels of vitamin D have up to a $45 \%$ decrease in the risk of BC compared to those with low levels [28], moreover, adequate vitamin $\mathrm{D}$ levels predict better diseasefree and overall survival in female with breast cancer [5]. The positive effects of vitamin D on BC occurrence and survival possibly linked to its anti-proliferative or immuno-regulatory effect. Insufficient data are available regarding the effect of vitamin $\mathrm{D}$ on numerous prognostic factors in breast cancer, and understanding of how vitamin $\mathrm{D}$ affects these prognostic indicators may clarify methods via which vitamin $\mathrm{D}$ controls BC evolution and survival.

In our study, mean vitamin D level was $28.7 \mathrm{ng} / \mathrm{ml}$, and median was $20 \mathrm{ng} / \mathrm{ml}$ (range, $5 \mathrm{ng} / \mathrm{ml}$ to $98 \mathrm{ng} / \mathrm{ml}$ ), and the serum level of $25(\mathrm{OH}) \mathrm{D}$ was sufficient only in $31 \%$ of patients, deficient in $36.9 \%$

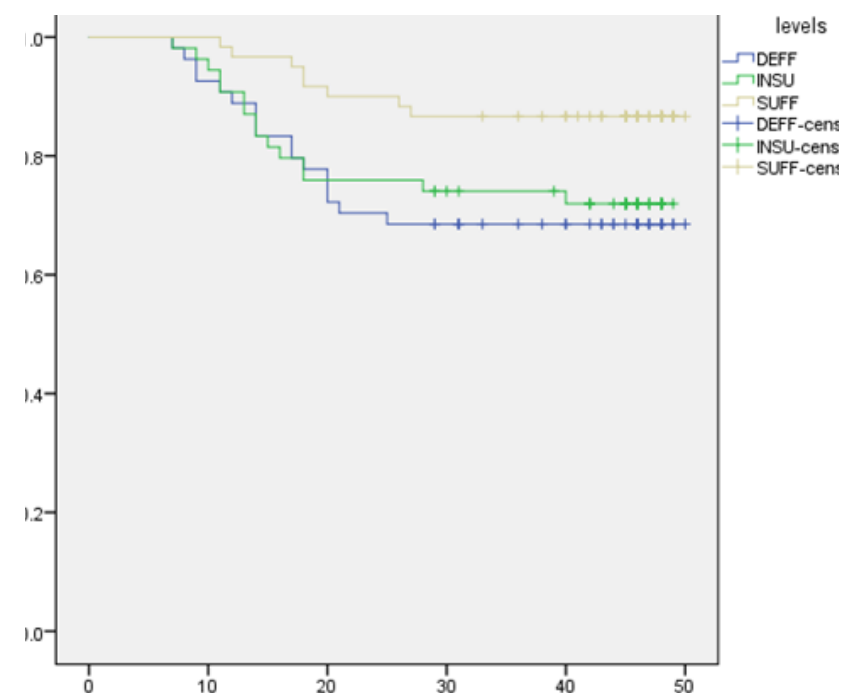

Figure 2: overall survival (OS) of the 3 different category groups of serum vit $\mathrm{D}$ in all breast cancer patients.

and insufficient in $32.1 \%$ of patients. In Egypt, the prevalence of vit D deficiency in female has been shown to be between $25 \%$ to $69 \%$, and this is consistent with our results. Elzehery et al. [29] reported 25(OH) vitamin D levels were significantly lower in the patients with BC $(22.1$ $\pm 10.9 \mathrm{ng} / \mathrm{ml}$ ) compared to controls $(\mathrm{p}=0.001)$ in Egypt, and Vitamin $\mathrm{D}$ deficiency-insufficiency was reported in $76.7 \%$ of BC patients. Also, Ghasem et al. [30] reported that, mean serum vitamin D was $22.58 \pm$ $14.21 \mathrm{ng} / \mathrm{ml}$ in 200 patients, $23.5 \%$ had severe deficiency, $37.5 \%$ had mild deficiency and $39.0 \%$ had sufficient vitamin D levels in serum, and this agreed with our results. But in the study done by Abdelgawad et al. [31], the median serum levels of $25-\mathrm{OH}$ Vit D were $15 \mathrm{ng} / \mathrm{ml}$ in the breast cancer patients, while it was $21 \mathrm{ng} / \mathrm{ml}$ in the control group, and Vit D was deficient in $67 \%$ of the breast cancer patients, their lower vit $\mathrm{D}$ level and higher percentage of vit $\mathrm{D}$ deficiency in breast cancer patients than our results, may be due to different residency and minor (98 patient) sample size, or due to different cut-off levels for optimal 25-hydroxy vitamin-D which may influence results.

In Middle East countries, the prevalence of vit D deficiency were between $30 \%$ to $80 \%$ [32-35], with female predominance [35] and this is compatible with our findings.

Conflicting data from numerous studies about the link between vitamin $\mathrm{D}$ deficiency and breast cancer risk, and in review of the literature, many studies have been done to correlate the conventional prognostic factors of breast cancer with vitamin $\mathrm{D}$ deficiency, but the results of these studies were inconsistent [36,37], so other randomized control trials appears to be required for resolving these controversies.

We found statistically significant relations between serum $25(\mathrm{OH})$ $\mathrm{D}$ levels with tumor size, stage, number of positive lymph nodes, and ki-67.

Hatse et al. [14] study demonstrated lower levels of vitamin D in breast cancer patients significantly correlated to only tumor size not to other prognostic features of tumor. Also, we found vit D levels decreased significantly with increasing BMI $(\mathrm{p}=0.00)$. Our observation about the significant association between vitamin D lack and high KI- 67 level advocates that the prognostic effect of vitamin D may be to somewhat; 


\begin{tabular}{|c|c|c|c|c|}
\hline \multicolumn{5}{|c|}{ Overall survival } \\
\hline \multirow{2}{*}{ Prognostic factors } & \multirow{2}{*}{ Univariate analysis } & \multicolumn{3}{|c|}{ Multivariate analysis } \\
\hline & & HR & $95 \% \mathrm{Cl}$ & $P$ value \\
\hline Age & 0.014 & 2.1 & $1.146-4.064$ & 0.01 \\
\hline Menopausal status & 0.11 & 0.78 & $0.572-01.066$ & 0.11 \\
\hline BMI & 0.002 & 2.252 & $1.378-3.680$ & 0.001 \\
\hline Grade & 0.002 & 0.807 & $0.471-1.382$ & 0.435 \\
\hline Stage & 0.002 & 0.296 & $0.215-0.407$ & $<0.0001$ \\
\hline Molecular type & $<0.0001$ & 1.271 & $0.897-1.802$ & 0.177 \\
\hline Vitamin D levels & 0.047 & 0.63 & $0.434-0.936$ & 0.022 \\
\hline
\end{tabular}

Table 2: Univariate and multivariate analysis of prognostic factors and Overall survival of breast cancer patients.

due to progress to high grade tumor in vitamin D lacking female, numerous studies verified that vitamin $\mathrm{D}$ in breast cancer can improve prognosis throughout apoptosis initiation [14,38]. This advocates that vitamin D supplementation following breast cancer diagnosis may affect the prognosis.

Amir et al. [39] reported elevated BMI was connected to increase risk of breast cancer, and there was a statistically significant (but very weak) negative relationship of BMI with 25-hydroxy vitamin-D level. The negative relation between 25-hydroxy vitamin-D and BMI has been reported before [40], this link may be due to deficiency of sunlight exposure from physical immobility, or presence of excess adipose tissue in overweight and obese individuals that lead to decrease bioavailability and distribution of fat-soluble vitamin-D metabolites [41].

We found the level of $25(\mathrm{OH})$ vitamin $\mathrm{D}$ was significantly inferior in metastatic cases in comparison to non-metastatic $(\mathrm{p}=0.01)$, this is in consistent with Palmieri et al. [42] who reported serum levels of $25(\mathrm{OH}) \mathrm{D}$ are significantly elevated in early breast cancer cases than in those with advanced disease, while the study by Iraj et al. [17] reported that serum vitamin $\mathrm{D}$ was significantly higher in metastatic breast cancer patients than those without metastasis, $21 \%$ of their patients had metastases mainly in bone, which may explain the reason of higher level of $25(\mathrm{OH}) \mathrm{D}$ in metastatic patients in their study.

Regarding molecular subtypes, we found luminal B had significantly deficient vit d levels, while luminal A had significantly sufficient levels $(\mathrm{p}=0.03$ ), and no statistically significance difference was found in Vitamin D levels according to menopausal status $(\mathrm{p}=0.69)$, this was consistent with Ghasem et al in 2016 [30] who reported, patients with distant metastases, higher tumor grade, larger tumor size, had significantly lower serum vitamin D levels ( $p=0.001, p<0.0001, p=0.021$ respectively), but Vitamin D level was a little different between pre and post-menopausal status and between hormone receptor-positive and hormone receptor-negative patients, but this was not statistically significant. Larsson et al. in 2009 [43] showed correlation between vitamin $\mathrm{D}$ insufficiency and estrogen and progesterone receptor negative breast cancer, but no relation to other tumor characteristics. Also, Song Yao et al. in 2016 [44] reported that serum 25 OHD concentrations were lower in women with advanced stage, and the lowest in premenopausal women with triple-negative cancer. Kim et al. in 2011 [45] found a significant relation between deficient vitamin D and poor prognosis in breast cancer and triple negative tumors, also the study of Peppon et al. in 2012 [46] has revealed a link between deficiency of vitamin D and increased risk of (ER-) breast cancer, while in the study done by Imtiaz et al. in 2012 [47] no relation between vitamin D levels and tumor prognostic features. Also, Goodwin et al. [11] reported no significant relation between tumor stag, number of lymph node involvement or ER status and serum25 (OH) D level in breast cancer patients.
We studied the relation between serum $25(\mathrm{OH}) \mathrm{D}$ and survival in $\mathrm{BC}$ patients, our results put in to the rising body of literature on the possible link connecting serum vitamin D and survival of breast cancer. We did not find a significant association between serum vitamin $\mathrm{D}$ and disease-free survival (DFS) in non-metastatic $\mathrm{BC}$ or progression free survival (PFS) in metastatic BC in our study of newly diagnosed BC patients. But regarding the overall survival of all our patients, patients with sufficient serum vit $\mathrm{D}$ level have better OS comparing to those with insufficient or deficient levels ( $\mathrm{p}=0.047)$.

Our results are consistent with a meta-analysis which was conducted to assess the association between $25(\mathrm{OH}) \mathrm{D}$ and breast cancer mortality, and it discovered higher serum levels of $25(\mathrm{OH}) \mathrm{D}$ leading to decrease case-mortality rates after breast cancer diagnosis [48].

In large cohort study of 1666 women with breast cancer, higher serum 25-hydroxyvitamin D levels were independently associated with better outcomes, including disease free and overall survival [44], according to investigators, the linkage between vitamin $\mathrm{D}$ and breast cancer possibly connected to the vitamin role in enhancing normal mammary-cell development, and initiating the death of cancer cells.

There is still little information about the possible link between vitamin D and BC recurrence, so Jacobs et al. in 2011 [49] conducted a study in which 3085 women with BC and 512 controls were enrolled, and results indicated no relation between $25(\mathrm{OH}) \mathrm{D}$ level and $\mathrm{BC}$ recurrence, but previously Goodwin and his colleagues [11] reported an increased risk of distant recurrence and death among women with $25(\mathrm{OH}) \mathrm{D}$ concentrations $<20 \mathrm{ng} / \mathrm{ml}$. This variation in results may be because of confounding factors such as exercise, sunlight exposure, nutritional status or smoking; also, the treatments of patients were not similar, leading to some limitations of our results. Moreover, in our study, serum $25(\mathrm{OH}) \mathrm{D}$ was measured once only at the time of diagnosis, and this may not reflect the true vitamin D levels during carcinogenesis or progression. However, previous research has shown the reliability of a single serum vitamin D assessment over a 5-year period [50]. But also, there is some power of our study, as we enrolled a consistent patient population of newly diagnosed breast cancer which minimizes potential confusing by previous treatment history. We assessed serum vitamin $\mathrm{D}$ at diagnosis before any treatment which reduces the possibility of affecting serum vitamin D levels by treatment or lifestyle changes after diagnosis, also we had adequate sample size of histologically confirmed breast cancer, and using a consecutive case series of all eligible patients in our hospital during a fixed period, so we decrease the probability of collection bias in this study.

The mechanisms by which serum vit $\mathrm{D}$ level can affect the survival of cancer patients were investigated in many studies, and that could be explained in several ways, first: serum vitamin $\mathrm{D}$ can inhibit the expansion and angiogenesis of cancer cells mostly due to the inhibition 
of response to vascular endothelial growth factor [51]. Moreover, serum vitamin D represses epidermal growth factor receptor, which control a lot of oncogenesis mechanisms, like proliferation and metastasis [52]. Lastly, serum vitamin D has may increase the secretion of protein glues, for example: E-cadherin and catenin, leading to more adherences of the cells to each other so decreasing metastases [53].

\section{Conclusion}

In summary, these results provide a support to the suggestion that vitamin $\mathrm{D}$ has a role in the pathogenesis and progression of breast cancer. Our research, although being an observational study, obviously demonstrates that serum vitamin $\mathrm{D}$ levels are significantly inferior in advanced breast cancer patients than in those with early stages, in addition sufficient serum vit $\mathrm{D}$ level decrease the mortality in breast cancer patients. On the other hand, numerous issues still unanswered, these including the possible causes and underlying processes that regulate vit $\mathrm{D}$ metabolism in breast cancer. Answering these questions may lead to improve the risk stratification, surveillance and treatment of breast cancer.

\section{References}

1. Siegel RL, Miller KD, Jemal A (2016) Cancer statistics. CA Cancer J Clin 66: 7-30.

2. Ibrahim AS, Khaled HM, Mikhail NN, Baraka H, Kamel H (2014) Cancer incidence in Egypt: Results of the national population-based cancer registry program. J Cancer Epidemiol 2014: 437971.

3. Basharat I, Zia N, Murad F, Malik AZ, Mahmood N (2014) Vitamin D Deficiency as a risk factor of breast cancer. J Rawalpindi Med College 18: 199-201.

4. Abbas S, Linseisen J, Slanger T, Kropp S, Mutschelknauss EJ, et al. (2008) Serum 25-hydroxyvitamin $D$ and risk of post-menopausal breast cancer-results of a large case-control study. Carcinogenesis 29: 93-99.

5. Colston KW, Hansen CM (2002) Mechanisms implicated in the growth regulatory effects of vitamin $D$ in breast cancer. Endocr Relat Cancer 9: 45-59.

6. John EM, Schwartz GG, Dreon DM, Koo J (1999) Vitamin D and breast cancer risk: The NHANES I epidemiologic follow-up study, 1971-1975 to 1992. Cancer Epidemiol Biomarkers Prev 8: 399-406.

7. Cui Y, Rohan TE (2006) Vitamin D, calcium, and breast cancer risk: A review. Cancer Epidemiol Biomarkers Prev 15: 1427-37.

8. Robien K, Cutler GJ, Lazovich D (2007) Vitamin D intake and breast cancer risk in postmenopausal women: The lowa women's health study. Cancer Causes Control 18: 775-82

9. Abbas S, Chang Claude J, Linseisen J (2009) Plasma 25- hydroxyvitamin D and premenopausal breast cancer risk in a German case-control study. Int $\mathrm{J}$ Cancer 124: 250-255.

10. Gissel T, Rejnmark L, Mosekilde L, Vestergaard P (2008) Intake of vitamin D and risk of breast cancer- A meta-analysis. J Steroid Biochemistry Molecular Biology 111: 195-199.

11. Goodwin PJ, Ennis M, Pritchard K, Koo J, Hood N (2009) Prognostic effects of 25-hydroxyvitamin D levels in early breast cancer. J Clin Oncol 27: 3757-63.

12. James SY, Mackay AG, Colston KW (1996) Effects of 1,25 dihydroxyvitamin D3 and its analogues on induction of apoptosis in breast cancer cells. J Steroid Biochem Mol Biol 58: 395-401.

13. Villaseñor A, Ballard Barbash R, Ambs A, Bernstein L, Baumgartner K, et al. (2013) Associations of serum 25- hydroxyvitamin D with overall and breas cancer-specific mortality in a multiethnic cohort of breast cancer survivors. Cancer Causes Control 24: 759-67.

14. Hatse S, Lambrechts D, Verstuyf A, Smeets A, Brouwers B, et al. (2012) Vitamin D status at breast cancer diagnosis: Correlation with tumor characteristics, disease outcome, and genetic determinants of vitamin D insufficiency. Carcinogenesis 33: 1319-1326.

15. Tretli S, Schwartz GG, Torjesen PA, Robsahm TE (2012) Serum levels of 25-hydroxyvitamin $D$ and survival in Norwegian patients with cancer of breast colon, lung, and lymphoma: A population based study. Cancer Causes Control 23: $363-370$.

16. Vrieling A, Hein R, Abbas S, Schneeweiss A, Flesch-Janys D, et al. (2012) Serum 25-hydroxyvitamin $D$ and postmenopausal breast cancer survival: A prospective patient cohort study. Breast cancer res 13: R74.

17. Kermani IA, Kojidi HT, Gharamaleki JV, Sanaat Z, Ziaei JE, et al. (2011) Association of serum level of 25 Hydroxy-Vitamin $D$ with prognostic factors for breast cancer. Asian Pac J Cancer Prev 12: 1381-84.

18. WHO Obesity preventing and managing the global epidemic. Geneva, Switzerland: World Health Organization: 2000

19. Oken MM, Creech RH, Tormey DC, Horton J, Davis TE, et al. (1988) Toxicity and response criteria of the Eastern Cooperative Oncology Group. AmJ Clin Oncol 5: 649-655.

20. Edge SB, Compton CC (2010) The American Joint Committee on Cancer: The $7^{\text {th }}$ edition of the AJCC cancer staging manual and the future of TNM. Ann Surg Oncol 17: 1471-1474.

21. Elston CW, Ellis IO (1991) Pathological prognostic factors in breast cancer. I. The value of histological grade in breast cancer: Experience from a large study with long-term follow-up. Histopathology 19: 403-410.

22. Hsu SM, Raine L, Fanger H (1981) Use of avidin-biotin-peroxidase complex $(A B C)$ in immunoperoxidase techniques: $A$ comparison between $A B C$ and unlabeled antibody (PAP) procedures. J HistochemCytochem 29: 577-580.

23. Thike AA, Chng MJ, Fook-Chong S, Tan PH (2001) Immunohistochemical expression of hormone receptors in invasive breast cancer: Correlation of results of $\mathrm{H}$-score with pathologic parameters. Pathology 33: 21-25.

24. Bang YJ, Van Cutsem E, Feyereislova A, Chung HC, Shen L, et al. (2010) Trastuzumab in combination with chemotherapy versus chemotherapy alone for treatment of HER2-positive. The Lancet 376: 687-697.

25. Tan PH, Chuah KL, Chiang G (2002) Correlation of p53 and cerbB2 expression and hormonal receptor status with clinicopathological parameters in ductal carcinoma in situ of the breast. Oncol Rep 9: 1081-1086.

26. Colston KW (2008) Vitamin D and breast cancer risk. Best Pract Res Clin End Met 22: 587-599.

27. Garland CF, Gorham ED, Mohr SB, Grant WB, Giovannucci EL, et al. (2007) Vitamin D and prevention of breast cancer: Pooled analysis. J Steroid Biochem Mol Biol. 103: 708-711.

28. Chen P, Hu P, Xie D, Qin Y, Wang F, et al. (2010) Meta-analysis of vitamin D, calcium and the prevention of breast cancer. Breast Cancer Res Treat. 121: 469-477.

29. Elzehery RR, Baiomy AA, Hegazy MAF, Fares R, Gilany AHEl, et al. (2016) Vitamin $D$ status, receptor gene Bsml (A/G) polymorphism and breast cancer in a group of Egyptian females. Egypt J Med Hum Genet.

30. Janbabai G, Shekarriz R, Hassanzadeh H, Aarabi M, Borhani SS (2016) A survey on the relationship between serum 25-hydroxy vitamin D level and tumor characteristics in patients with breast cancer. Int J Hematol Oncol Stem Cell Res 10: 30-36

31. Abdelgawad IA, E-Mously RH, Saber MM, Mansour OA, Shouman SA, (2015) Significance of serum levels of vitamin $D$ and some related minerals in breast cancer patients. Int J Clin Exp Pathol 8: 4074-4082.

32. Alagol F, Shihadeh Y, Boztepe H, Tanakol R, Yarman S, et al. (2000) Sunlight exposure and vitamin D in Turkish women. J Endocrinol Invest. 23: 173-177.

33. Niafar M, Bahrami A, Aliasgharzadeh A, Aghamohammadzadeh $N$ Najafipour F, et al. (2009) Vitamin D status in healthy postmenopausal Iranian women. J Res Med Sci 14: 171-177.

34. Dawodu A, Agarwal M, Hossain M, Kochiyil J, Zayed R (2003) Hype vitaminosis $D$ and vitamin $D$ deficiency in exclusively breast-feeding infants and their mother in summer: A justification for vitamin D supplementation of breast-feeding infants. J Pediatr 142: 169-173.

35. Hashemipour S, Larijani B, Adibi H, Javadi E, Sedaghat M, et al. (2004) Vitamin $\mathrm{D}$ deficiency and causative factors in the population of Tehran. BMC Public Health 4: 38 .

36. Simard A, Vobecky J, Vobecky JS (1991) Vitamin D deficiency and cancer of 
Citation: El-Shorbagy S, Haggag R, Ebian HF, Labib HA, Harb OA (2017) Prognostic Impact of 25-Hydroxyvitamin D Levels in Egyptian Patients with Breast Cancer. J Cancer Sci Ther 9: 496-502. doi: 10.4172/1948-5956.1000466

the breast: An unprovocative ecological hypothesis. Can J Public Health 82 : 300-303.

37. Frazier AL, Ryan CT, Rockett H, (2003) Adolescent diet and risk of breast cancer. Breast Cancer Res 5: R59-64.

38. Mathiasen IS, Lademann U, Jaattela M (1999) Apoptosis induced by vitamin $\mathrm{D}$ compounds in breast cancer cells is inhibited by Bcl-2 but does not involve known caspases or p53. Cancer Res 59: 4848-4856.

39. Amir E, Cecchini RS, Ganz PA, Costantino JP, Beddows S, et al. (2012) 25-Hydroxy vitamin-D, obesity, and associated variables as predictors of breast cancer risk and tamoxifen benefit in NSABP-P1. Breast Cancer Res Treat 133 1077-1088.

40. Muscogiuri G, Sorice GP, Prioletta A, Policola C, Della Casa S, et al. (2010) 25-Hydroxyvitamin D concentration correlates with insulin-sensitivity and BM in obesity. Obesity (Silver Spring) 18: 1906-1910.

41. Wortsman J, Matsuoka LY, Chen TC, Lu Z, Holick MF, (2000) Decreased bioavailability of vitamin D in obesity. Am J Clin Nutr. 72: 690-693.

42. Palmieri C, MacGregor T, Girgis S, Vigushin D, (2006) Serum 25-hydroxyvitamin $\mathrm{D}$ levels in early and advanced breast cancer. J Clin Pathol 59: 1334-1336.

43. Larsson SC, Bergkvist L, Wolk A (2009) Long-term dietary calcium intake and breast cancer risk in a prospective cohort of women. Am J Clin Nutr, 89: $277-282$.

44. Yao S, Kwan M, Ergas I (2016) Association of serum level of vitamin D at diagnosis with breast cancer survival: A case-cohort analysis in the pathways study. JAMA Oncol 3: 351-357.

45. Kim HJ1, Lee YM, Ko BS, Lee JW, Yu JH, et al. (2011) Vitamin D deficiency is correlated with poor outcomes in patients with luminal type breast cancer. Ann Surg Oncol 18: 1830-1836.
46. Peppone LJ, Rickles AS, Janelsins MC, Insalaco MR, Skinner KA, (2012) The association between breast cancer prognostic indicators and serum $25-\mathrm{OH}$ vitamin D levels. Ann Surg Oncol 19: 2590-2599.

47. Imtiaz S, Siddiqui N, Raza SA, Loya A, Muhammad A, (2012) Vitamin D deficiency in newly diagnosed breast cancer patients. Indian $\mathrm{J}$ Endocr Metab 16: 409-413.

48. Mohr SB, Gorham ED, Kim J, Hofflich H, Garland CF, (2014) Meta-analysis of Vitamin D sufficiency for improving survival of patients with breast cancer. Anticancer Research 34: 1163-1166.

49. Jacobs ET, Thomson CA, Flatt SW, Al-Delaimy WK, Hibler EA, et al. (2011) Vitamin $D$ and breast cancer recurrence in the Women's Healthy Eating and Living (WHEL) study. Am J Clin Nutr 93: 108-117.

50. Hofmann JN, Yu K, Horst RL, Hayes RB, Purdue MP (2010) Long-term variation in serum 25 -hydroxyvitamin $D$ concentration among participants in the prostate, lung, colorectal, and ovarian cancer screening trial. Cancer Epidemiol Biomarkers Prev 19: 927-931.

51. Nakagawa K, Sasaki Y, Kato S (2005) 22-Oxa-1alpha,25-dihydroxyvitamin D3 inhibits metastasis and angiogenesis in lung cancer. Carcinogenesis 26 1044-1054.

52. Herbst RS, Heymach JV, Lippman SM (2008) Lung cancer. N Engl J Med 359 1367-1380.

53. Zhou W, Suk R, Liu G, Park S, Neuberg DS, et al. (2005) Vitamin D is associated with improved survival in early-stage non-small cell lung cancer patients. Cancer Epidemiol Biomarkers Prev 14: 2303-2309. 